\title{
ANALISIS RANTAI NILAI AGROINDUSTRI SAGU DI KABUPATEN KEPULAUAN MERANTI
}

\section{VALUE CHAIN ANALYSIS OF SAGO INDUSTRY IN KEPULAUAN MERANTI DISTRICT}

\author{
Gusti Randy Pratama ${ }^{1 *}$, Hartrisari Hardjomidjojo ${ }^{1)}$, Ade Iskandar'), Tjahja Muhandri' ${ }^{2)}$ \\ ${ }^{1)}$ Departemen Teknologi Industri Pertanian, Fakultas Teknologi Pertanian, Institut Pertanian Bogor, \\ Kampus IPB Darmaga, PO BOX 220 16602, Bogor, Indonesia \\ *Email penulis untuk korespondensi : gustirandy@gmail.com \\ ${ }^{2)}$ Departemen Ilmu dan Teknologi Pangan, Fakultas Teknologi Pertanian, Institut Pertanian Bogor \\ Makalah: Diterima 3 Mei 2018; Diperbaiki 10 Agustus 2018; Disetujui 23 Agustus 2018
}

\begin{abstract}
Sago industries in Kepulauan Meranti holds an important position in driving the local economy. Around 80,000-90,000 tons of sago starch are produced annually by sago mills generally located in rural areas. Almost all of the sago starch production from the Kepulauan Meranti is sent out of the region as raw material for the next industry. Lack of market information related to price, quality, quantity and types of products that the market wants makes the sago industry only rely on information from the midleman. Sago has significant value to be utilized into various commercial products such as modified starch, glucose, food thickener, noodles and biscuits. The purpose of this study were (1) to map the sago industry value chain and (2) to identify the distribution of values to the actors involved. Data collection includes key informant interviews, focus group discussions, observation and collection of related documents. Data analysis used includes value chain analysis, marketing margin analysis and value added analysis. The results of this study indicated that there are various actors involved in the sago industry value chain starting from seed suppliers, sago smallholders, PT. NSP, log traders, wet sago mills, dry sago mills, glass noodles factories, home industries, Harmonis Cooperatives, individual distributors and PT. Saweri Gading. In the wet sago value chain, PT. Saweri Gading obtained a higher marketing margin than the sago mills, with a margin of Rp 2,000 per $\mathrm{kg}$. In the dry sago value chain, sago mills actors obtained a margin of $R p 4,600 \mathrm{per} k g$. The results of the value added analysis showed that glass noodles products have value added of Rp 3,450 per $\mathrm{kg}$, the highest value added compared to other sago industry products.
\end{abstract}

Key words : Kepulauan Meranti, sago industry, value added, value chain

\section{ABSTRAK}

Agroindustri sagu di Kabupaten Kepulauan Meranti menduduki posisi penting dalam penggerak ekonomi daerah. Sekitar 80.000-90.000 ton sagu kering diproduksi setiap tahun oleh kilang sagu yang umumnya berlokasi di area pedesaan. Hampir semua produksi pati sagu dari Kepulauan Meranti dikirim ke luar daerah sebagai bahan baku pada industri selanjutnya. Lemahnya informasi pasar terkait harga, kualitas, kuantitas dan jenis produk yang diinginkan pasar menyebabkan agroindustri sagu cenderung mengandalkan informasi dari pedagang perantara. Sagu memiliki nilai yang signifikan untuk dimanfaatkan menjadi berbagai produk komersial seperti pati modifikasi, glukosa, pengental makanan, mie dan biskuit. Tujuan dari penelitian ini (1) memetakan rantai nilai agroindustri sagu dan (2) mengidentifikasi distribusi nilai pada aktor yang terlibat. Pengumpulan data meliputi key informant interviews, focus group discussion, observasi dan pengumpulan dokumen terkait. Analisa data yang digunakan meliputi analisis rantai nilai, analisis margin pemasaran dan analisis nilai tambah. Hasil penelitian ini menunjukkan terdapat berbagai aktor yang terlibat pada rantai nilai agroindustri sagu mulai dari pemasok bibit, petani sagu, PT. NSP, pedagang tual, kilang sagu basah, kilang sagu kering, pabrik sohun, industri rumah tangga, Koperasi Harmonis, distributor individu dan PT. Saweri Gading. Pada rantai nilai sagu basah, aktor PT. Saweri Gading memperoleh margin pemasaran lebih tinggi dari kilang sagu, dengan perolehan margin sebesar Rp 2.000 per kg. Pada rantai nilai sagu kering, aktor kilang sagu memperoleh margin Rp 4.600 per $\mathrm{kg}$. Hasil analisis nilai tambah menunjukkan produk sohun memperoleh nilai tambah sebesar Rp 3.450 per $\mathrm{kg}$, nilai tambah tersebut tertinggi dibandingkan produk agroindustri sagu lainnya.

Kata kunci : agroindustri sagu, Kepulauan Meranti, nilai tambah, rantai nilai

\section{PENDAHULUAN}

Pohon sagu memiliki nilai yang signifikan untuk dimanfaatkan menjadi berbagai produk komersial seperti pati modifikasi, asam laktat, siklodekstrin dan etanol (Singhal et al., 2008;
Sunarti et al., 2017). Di Asia Tenggara khususnya, pati sagu telah digunakan untuk memasak berbagai jenis hidangan seperti jeli, puding, sup, pengental makanan, mie, biskuit dan sagu mutiara (Karim et al., 2008). Menurut Bujang (2010), di Malaysia sekitar 100.000 ton pati sagu digunakan setiap 
tahunnya untuk berbagai aplikasi, terutama dalam produksi glukosa (15.600 ton), MSG (15.000 ton) dan mie (13.200 ton) sedangkan kebutuhan rumah tangga lainnya menggunakan 36.000 ton.

Pati yang diekstrak dari batang pohon sagu, menawarkan potensi yang cukup besar sebagai bahan baku untuk industri pengolahan skala kecil, menengah dan besar serta menjadi diversifikasi berbagai produk (FAO, 2013). Menurut Nusantara el al. (2014) diversifikasi produk pertanian, akan menjadikan produk pertanian lebih terbuka ke pasar yang lebih luas, tidak hanya di pasar domestik tapi juga pasar luar negeri. Namun, kurangnya strategi pemasaran yang mengedepankan sagu sebagai pati serbaguna, pengembangan produk sagu di segmen pasar tertentu dan ekspansi pasar untuk produk sagu yang dihasilkan oleh usaha kecil menengah menjadi tantangan dalam pengembangan agroindustri sagu (FAO, 2013).

Agroindustri sagu di Kabupaten Kepulauan Meranti menduduki posisi penting dalam penggerak ekonomi daerah. Sekitar 80.000-90.000 ton sagu kering diproduksi setiap tahun oleh kilang sagu dengan kapasitas produksi mulai dari 50 hingga 200 ton per bulan (Ehara et al., 2018). Agroindustri sagu di Kepulauan Meranti pada umumnya diklasifikasikan sebagai usaha skala kecil dengan produk yang dihasilkan berupa sagu kering dan sagu basah (Hamidi dan Elida, 2018). Hampir semua produksi sagu kering dari Kepulauan Meranti dikirim ke Cirebon, Jawa Barat sebagai bahan baku industri sohun (Metaragakusuma et al., 2017), sedangkan sagu basah diekspor ke kilang sagu yang berada di Batu Pahat, Malaysia (Ehara et al., 2018).

Lemahnya informasi pasar seperti harga produk di pasar, kualitas, kuantitas dan jenis produk yang dibutuhkan di pasar, agroindustri sagu cenderung menegosiasikan harga produk mereka berdasarkan informasi yang diberikan oleh pedagang perantara. Menurut Kouwenhoven et al. (2012), informasi yang umumnya diberikan oleh pedagang perantara adalah terkait harga dan volume. Informasi seperti ini membuat rantai nilai lebih reaktif dari pada proaktif dan oleh sebab itu kemungkinan penambahan nilai, standar kualitas dan aspek kritis lainnya jarang dipikirkan, dibahas dan diperbaiki (Kouwenhoven et al., 2012). Baik produsen maupun pembeli akhir dari rantai nilai biasanya ingin memotong perantara dan menginginkan pasar yang lebih kompetitif untuk mengejar nilai, peningkatan kualitas dan jaminan produk (Da Silva et al., 2009).

Rantai nilai merupakan serangkaian aktivitas yang dilakukan untuk membawa sebuah produk atau layanan dari konsepsi, melalui tahapan produksi yang berbeda dengan melibatkan kombinasi transformasi fisik dan masukan dari berbagai layanan produsen, pengiriman ke konsumen akhir dan pembuangan akhir setelah digunakan (Kaplinsky dan Morris, 2001). Rantai nilai memiliki tiga atau lebih aktor, baik dalam bentuk organisasi atau individu ataupun keduanya (Watabaji et al., 2016).

Kaplinsky dan Morris (2001) mengamati bahwa dalam perjalanan globalisasi, telah terjadi sebuah persepsi kesenjangan pendapatan di dalam dan antar negara meningkat. Alasan utama mengapa analisis rantai nilai penting adalah membantu menjelaskan distribusi nilai, terutama pendapatan, kepada mereka yang berpartisipasi di dalam ekonomi global (Kaplinsky dan Morris, 2001). Ini melibatkan analisis margin dan keuntungan dalam rantai dan oleh karena itu dapat menentukan siapa yang diuntungkan dari keikutsertaan dalam rantai dan siapa yang memerlukan dukungan untuk memperbaiki kinerja dan keuntungan (M4P, 2008).

Tujuan dari penelitian ini yaitu (1) memetakan rantai nilai agroindustri sagu di Kabupaten Kepulauan Meranti, dengan memahami karakteristik aktor pada rantai dan hubungan diantara aktor yang terlibat, termasuk studi aliran produk olahan sagu melalui rantai, jenis proses atau kegiatan. (2) Mengidentifikasi distribusi nilai pada rantai agroindustri sagu, dengan memahami margin pemasaran dan nilai tambah yang diperoleh setiap aktor yang terlibat pada rantai nilai.

\section{METODE PENELITIAN}

\section{Kerangka pemikiran}

Seperti ditunjukkan pada Gambar 1, analisis rantai nilai meliputi dua kegiatan yang merupakan tujuan dari penelitian ini yaitu pemetaan rantai nilai dan identifikasi distribusi nilai pada aktor yang terlibat. Pengumpulan data mulai dilakukan pada bulan Mei 2017, teknik yang digunakan meliputi :

\section{Key Informant Interviews (KII) \\ KII digunakan untuk mendapatkan} informasi yang mendalam dari seseorang yang biasanya telah diketahui orang tersebut memiliki pengetahuan pada subjek tertentu (Elmendorf dan Luloff, 2006). Teknik ini digunakan untuk mewawancarai aktor rantai nilai mulai dari pemasok bibit, petani sagu, pedagang tual, pemilik kilang sagu basah, pemilik kilang sagu kering, pemilik pabrik sohun, pemilik industri rumah tangga, koperasi dan distributor. Selain aktor rantai nilai, wawancara juga dilakukan pada pengambil kebijakan dari dinas pemerintah terkait.

\section{Focus Group Discussion (FGD)}

FGD sebagai metodologi pengumpulan data kualitatif yang dilakukan secara berkelompok dengan proses wawancara berlangsung secara struktur, semi struktur ataupun tidak terstruktur (Boateng, 2012). Teknik pengumpulan data ini dilakukan sebanyak dua kali yang dilakukan pada saat sebelum dan sesudah pengumpulan data di lapangan. 


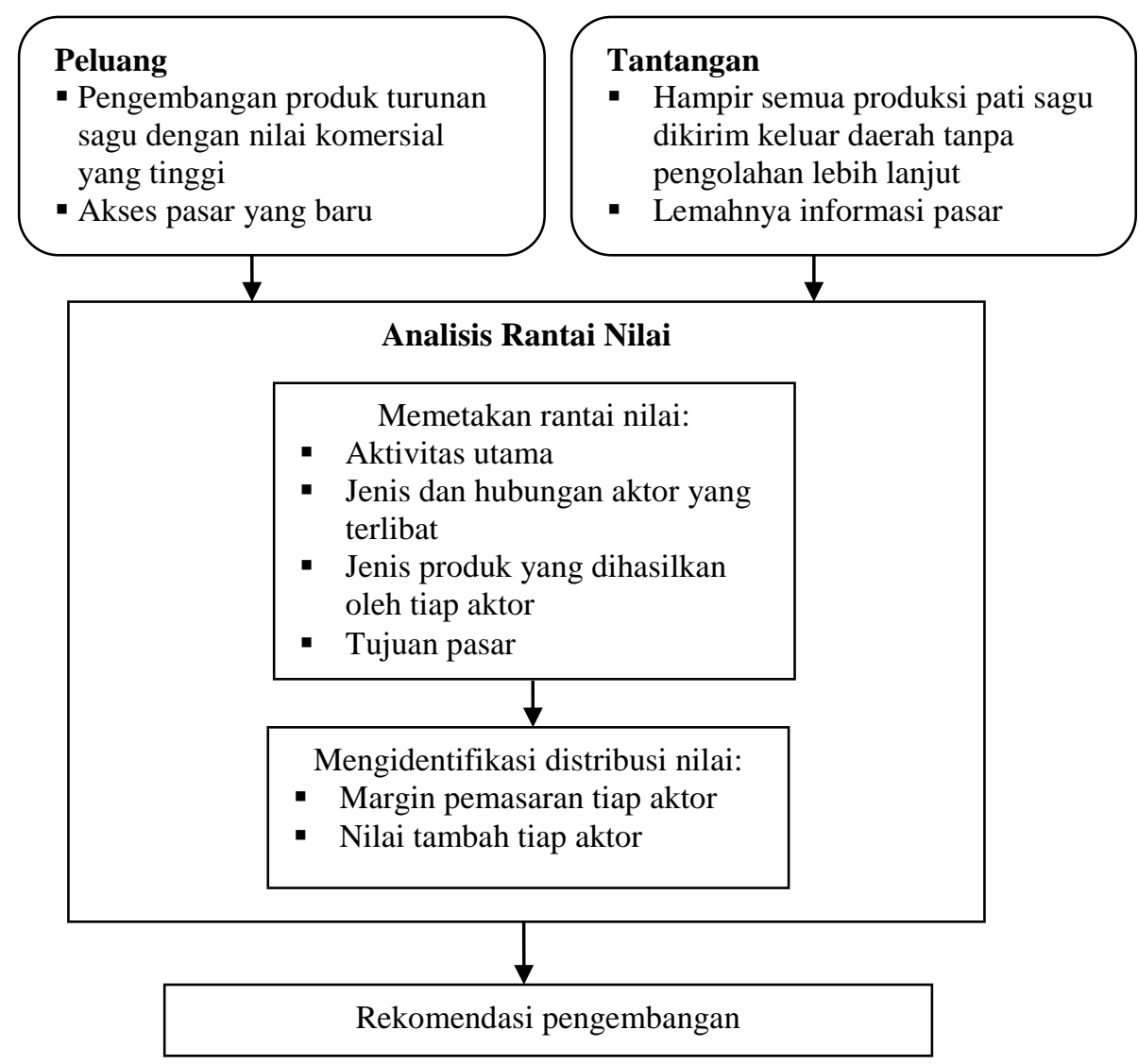

Gambar 1. Kerangka pemikiran

Responden yang hadir meliputi petani, pemilik kilang sagu, aparatur pemerintah yaitu Kepala Desa Sungai Tohor dan Direktur dari Wahana Lingkungan Hidup (WALHI) Riau yang merupakan lembaga swadaya masyarakat lokal pemerhati sagu. Dari FGD ini sekaligus memvalidasi temuan dari pengumpulan data di lapangan dan juga menambah informasi yang belum diketahui sebelumnya terkait rantai nilai agroindustri sagu di Kepulauan Meranti.

\section{Observasi}

Metode pengumpulan data dengan observasi dan pendekatan kualitatif berkontribusi pada penelitian dengan pengaturan secara alami sehingga mampu menjelaskan proses interaksi sosial dan fenomena yang terjadi (Jackson et al., 2016). Proses wawancara terhadap responden dari aktor rantai nilai yang ditemui, dilakukan secara langsung di lokasi aktor tersebut bekerja, sehingga dapat melakukan observasi terkait kondisi seperti proses produksi di kilang sagu, pabrik sohun, industri rumah tangga dan aktivitas budidaya oleh petani sagu.

\section{Dokumen}

Penelitian ini juga melakukan pengumpulan dokumen terkait dari responden yang ditemui. Dokumen tersebut didapatkan dari berbagai sumber antara lain laporan tahunan dari Dinas Perindustrian Perdagangan Koperasi dan UKM Kepulauan Meranti, laporan tahunan dari Dinas Perkebunan dan Holtikultura Kepulauan Meranti, laporan tahunan dari BPS Kepulauan Meranti, laporan tahunan dari perusahaan agroindustri sagu serta dokumen pendukung lainnya yang diperoleh dari media internet seperti jumlah produksi ekspor dan impor pati sagu.

\section{Analisis Data}

Data yang telah terkumpul, dianalisa dengan berbagai teknik analisis data antara lain :

\section{Analisis Rantai Nilai (ARN)}

Rantai nilai bisa dipetakan dan dianalisis menggunakan ARN (FAO, 2006). Sebagai alat deskriptif, ARN menitik beratkan analisis pada aspek mikro maupun makro yang terlibat dalam produksi dan pertukaran diantara aktor yang terlibat (Chagomoka et al., 2014). Peta rantai nilai merupakan inti dari ARN. Peta rantai nilai merupakan gambaran representasi visual dari sistem rantai nilai yang mengidentifikasi aktivitas bisnis (fungsi), aktor rantai dan hubungan antara aktor tersebut (Heinze dan Andreas, 2007).

Peta rantai nilai pada penelitian ini menggunakan model yang dikembangkan Heinze dan Andreas (2007). Model ini menghasilkan 
pemahaman pada peta rantai nilai terkait aktivitas utama, aktor utama, hubungan antara aktor dan pasar akhir dalam rantai nilai agroindustri sagu. Menurut M4P (2008) terdapat berbagai langkah dalam proses memetakan rantai nilai antara lain :

1. Memetakan proses inti dari rantai nilai.

2. Mengidentifikasi dan memetakan aktor utama yang terlibat di dalam proses.

3. Memetakan aliran produk.

4. Memetakan aliran informasi dan pengetahuan seperti standarisasi, regulasi dan sertifikasi.

5. Memetakan volume produk, jumlah aktor dan jenis pekerjaan tiap aktor.

6. Memetakan aliran geografis dari produk dan layanan.

7. Memetakan hubungan dan keterkaitan antar aktor rantai.

8. Memetakan peluang, kendala dan solusi potensial.

\section{Analisis Margin Pemasaran}

Margin pemasaran adalah perbedaan harga yang dibayar ke petani dan harga yang dibayar oleh konsumen dan itu pada umumnya digunakan untuk mengukur kinerja sistem pemasaran (Mumbeya, 2011). Menurut Phiri et al. (2013) rumus menghitung margin pemasaran sebagai berikut:

$$
\mathrm{MP}=\mathrm{HJ}-\mathrm{HP}
$$

\section{Keterangan :}

MP : Margin pemasaran $(\mathrm{Rp} / \mathrm{kg})$

HJ : Harga jual komoditas / produk ( Rp/kg)

HP : Harga pembelian komoditas / produk $(\mathrm{Rp} / \mathrm{kg})$

\section{Analisis Nilai Tambah}

Analisis nilai tambah dilakukan pada setiap aktor di sepanjang rantai nilai (Trienekens, 2011). Analisis nilai tambah pada penelitian ini menggunakan model yang dikembangkan oleh Hayami et al. (1987). Pengembangan agroindustri sagu berdasarkan perolehan dua kritera nilai tambah, yaitu :

1. Jika Nilai Tambah $(\mathrm{NT})>0$, berarti pengembangan agroindustri sagu memberikan nilai tambah yang hasilnya positif.

2. Jika NT $<0$, berarti pengembangan agroindustri sagu tidak memberikan nilai tambah dan hasilnya negatif.

\section{HASIL DAN PEMBAHASAN}

\section{Analisis Rantai Nilai}

Rantai nilai adalah serangkaian aktivitas yang dibutuhkan untuk membuat dan menambahkan nilai pada suatu produk (Kaplinsky dan Morris, 2001; Lie et al., 2012). Aktivitas utama pada rantai nilai agroindustri sagu di Kepulauan Meranti dimulai dari pembibitan, budidaya, pemanenan, pengolahan hulu, pengolahan hilir dan distribusi (Gambar 2). Setiap aktivitas rantai nilai tersebut melibatkan sejumlah aktor.

Rantai nilai memiliki tiga atau lebih aktor, baik dalam bentuk organisasi atau individu ataupun keduanya (Watabaji et al., 2016), seperti pada aktivitas pengolahan hulu terdapat aktor kilang sagu kering dan basah. Kilang sagu kering terbagi dua kategori yaitu kilang sagu milik PT National Sago Prima (NSP) dan kilang sagu rakyat. Kilang sagu rakyat memiliki pengolahan yang masih tradisional dan jumlahnya mencapai 72 unit pada kilang sagu kering dan 22 unit pada kilang sagu basah yang lokasinya tersebar di berbagai wilayah di Kepulauan Meranti.

Aktivitas pengolahan hilir dikerjakan oleh dua jenis aktor yaitu pabrik sohun dan industri rumah tangga. Kedua aktor tersebut menggunakan sagu basah sebagai bahan baku produksi. Pabrik sohun menggunakan sagu basah untuk sohun dan tepung hunkwe, sedangkan industri rumah tangga menggunakan sagu basah untuk menghasilkan mie sagu. Saat ini terdapat 4 unit pabrik sohun skala kecil menengah di Kepulauan Meranti dengan ratarata jumlah produksi harian sebanyak $300 \mathrm{~kg}$ untuk sohun dan $200 \mathrm{~kg}$ untuk tepung hunkwe.

Analisis rantai nilai menguji semua aktor yang terlibat di dalam rantai, hubungan antar aktor dan aktivitas disetiap hubungan (Lie et al., 2012). Hubungan tiap aktor tersebut ada yang kontrak dan tidak terikat. Aktor kilang sagu basah yang menjual produknya kepada PT. Saweri Gading, kedua aktor tersebut membuat hubungan kontrak setiap bulan. Begitu juga kilang sagu kering yang sudah menjadi anggota dari Koperasi Harmonis, hasil produksi dari kilang sagu tersebut harus didistribusikan melalui Koperasi. Hubungan tidak terikat, teridentifikasi pada pabrik sohun dengan kilang sagu basah. Kedua aktor tersebut terhubung bila adanya permintaan sagu basah dari pabrik sohun itu sendiri dan selanjutnya kilang sagu basah mengirimkan hasil produknya ke lokasi pabrik sohun tersebut.

\section{Deskripsi Aktor Rantai Nilai \\ Pemasok Bibit}

Pemasok bibit merupakan individu, kelompok ataupun perusahaan yang menjual bibit sagu. Aktivitas pemasok bibit dimulai dari pengambilan bibit dari anakan pohon sagu yang tumbuh, setelah itu diangkat dan dipindahkan ke area pembibitan. Bibit sagu dalam penyebutan masyarakat setempat dinamai "abut". Terdapat tiga jenis sagu yang dibudidayakan yakni sagu duri, sagu sangka dan bemban. Harga bibit sagu duri dan sangka berkisar Rp 7.000-8.000 per bibit, sedangkan bibit bemban dengan harga Rp 10.000 per bibitnya. 


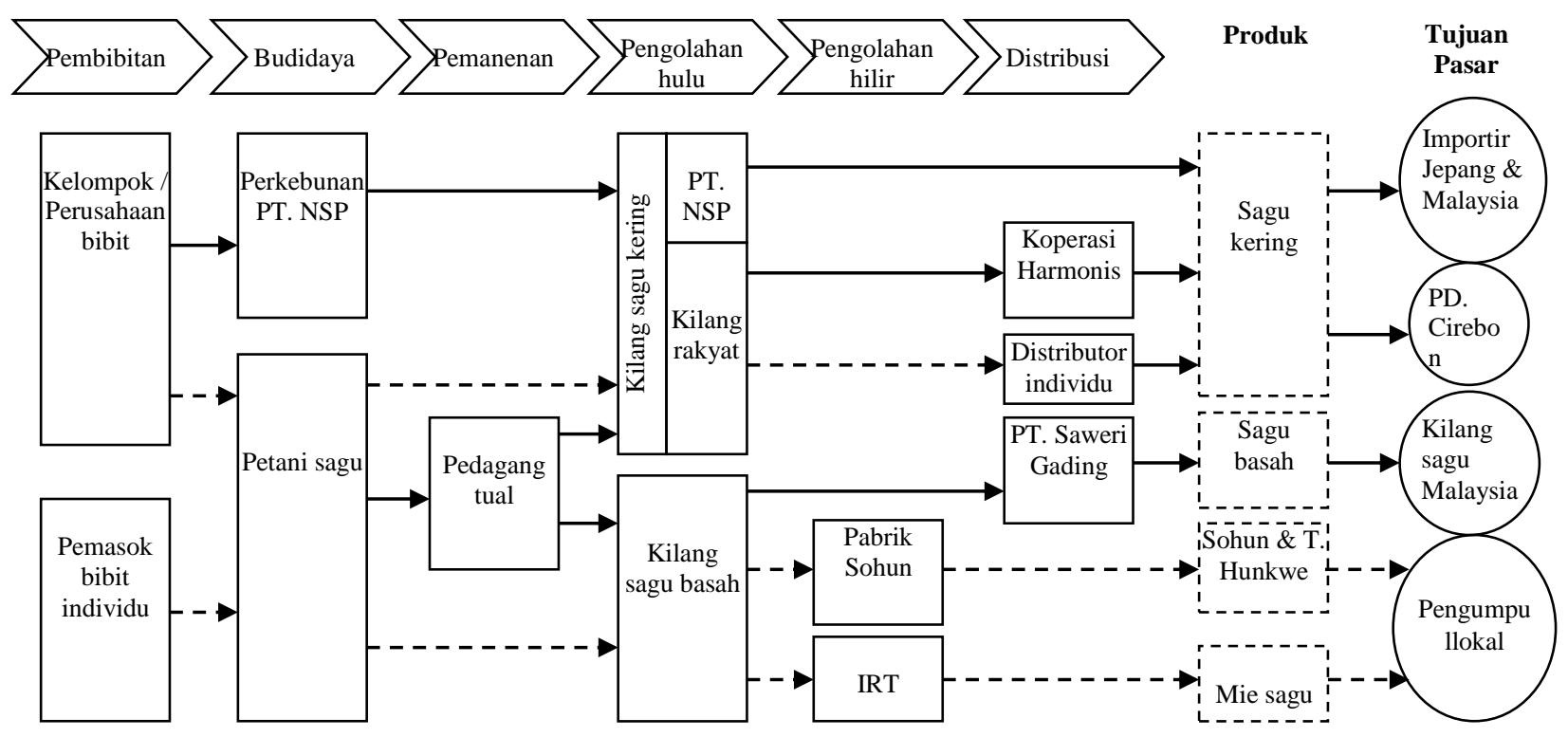

Keterangan $: \longrightarrow$ hubungan kontrak $---\rightarrow$ tidak terikat $\square$ Aktor rantai nilai

Gambar 2. Peta rantai nilai agroindustri sagu di Kepulauan Meranti

\section{Petani}

Aktivitas petani sagu dimulai dengan pembersihan lahan, penanaman abut (bibit sagu) dengan jarak $1,75 \mathrm{~m}$. Sistem penanaman dengan sebutan jalur, satu jalur bisa ditanami 40 bibit sagu dan satu hektar terdapat 3 jalur sehingga bisa ditanami 120 bibit sagu. Perawatan selama 3 tahun pertama dengan membersihkan dari tanaman pengganggu, setelah itu dibiarkan sampai menunggu masa panen. Pohon sagu mencapai masa panen setelah berumur 9 sampai 12 tahun dari sejak penanaman (Kamal et al., 2016).

Setelah memasuki usia panen, pohon sagu ditebang dan diambil batangnya untuk kemudian dijual ke kilang sagu. Petani menukarkan batang sagu menjadi uang sebagai sumber pendapatan yang dapat membuat petani membeli kebutuhan pokok seperti beras, makanan dan barang keperluan (Naim et al., 2016). Selain menjual dalam bentuk batang, terdapat petani yang menjual dalam bentuk satu pohon utuh dan belum ditebang. Utamanya pohon sagu tersebut dijual kepada pedagang tual. Harga satu pohonnya berkisar Rp 200.000-300.000.

\section{Pedagang Tual}

Aktivitas padagang tual ini bermula dari membeli pohon sagu dari petani yang sudah memasuki usia panen maupun yang belum memasuki usia panen atau dengan nama lain disebut dengan ijon. Batang sagu dibersihkan pelepah daunnya dan dipotong dengan panjang berkisar 1 meter untuk memudahkan pengiriman atau transportasi (Singhal et al., 2008). Bagian batang sagu yang sudah dipotong tersebut masyarakat lokal menyebutnya dengan tual. Satu pohon sagu rata-rata bisa menghasilkan 10 tual dengan berat rata-rata satu tualnya $100 \mathrm{~kg}$.

Aktor pedagang tual mempekerjakan 3-4 orang dalam membantu proses penebangan dan pengiriman tual sampai di lokasi kilang sagu. Pekerja diupah berdasarkan jumlah tual yang ditebang dan diangkut dari kebun ke kilang sagu. Besaran upah berkisar Rp 10.000 per tual bila jarak antara lokasi kebun dan kilang sagu kurang dari 500 $\mathrm{m}$, namun bila jarak lebih dari itu, pekerja diupah Rp 12.000 - Rp 16.000 per tualnya. Setelah keluar dari lokasi kebun, tual sagu dikirim ke kilang melalui aliran sungai dengan tual disusun seperti rakit (Singhal et al., 2008). Satu tual yang dijual pedagang ke kilang sagu dihargai Rp 35.000 45.000 tergantung dari kualitas tual sagu yang dihasilkan. Kualitas tual dilihat dari usia panen pohon sagu, ukuran tual dan cacat tidaknya tual sagu bila sampai di kilang yang biasanya diakibatkan dari proses pengiriman.

\section{Kilang Sagu Basah}

Tual sagu yang sudah sampai di lokasi kilang, proses selanjutnya akan diolah menjadi pati sagu. Satu tual bisa menghasilkan $30-35 \mathrm{~kg}$ sagu basah dengan nilai rendemen berkisar $35 \%$. Mayoritas kilang sagu basah berada di Desa Sungai Tohor, Kecamatan Tebing Tinggi Timur dengan jumlah 14 unit kilang sagu basah dan desa ini juga disebut sebagai sentra industri sagu di Kepulauan Meranti. Proses pengolahan tual menjadi sagu basah 
dimulai dari pengangkutan tual dari aliran sungai. Aliran sungai digunakan kilang sagu untuk menyimpan tual-tual yang dibeli untuk mengurangi deteriorasi (Singhal et al., 2008).

Setelah tual diangkat ke lokasi kilang, tual dikupas kulitnya dan dibelah menjadi ukuran kecil dengan menggunakan kampak. Tual yang sudah dibelah tersebut selanjutnya dimasukkan ke dalam mesin pemarutan yang sistem kerja mesin tersebut sama seperti mesin pemarut kelapa. Hasil parutan tual ditampung di dalam tangki berpengaduk untuk kemudian diisi dengan air dan selanjutnya proses ekstraksi yaitu pemisahan hampas dan pati sagu. Proses pemisahan pati dibantu dengan kain tapis (mesh) ukuran 100. Pati sagu yang telah terpisah dengan hampasnya diendapkan di kolam penampungan.

Selain dijual ke PT Saweri Gading, sagu basah juga dijual ke industri pengolahan hilir seperti pabrik sohun dan industri rumah tangga yang menghasilkan produk berbahan baku sagu basah namun masih dalam kapasitas produksi yang sedikit. Utamanya sagu basah dijual ke PT. Saweri Gading untuk diekspor ke Malaysia. Sagu basah yang dijual saat ini tidak memiliki kategori berdasarkan mutu, sehingga upaya peningkatan nilai tambah belum bisa diwujudkan pada jalur rantai nilai saat ini.

\section{Kilang Sagu Kering (Rakyat)}

Kilang sagu kering mengolah sagu dimulai dari tual. Proses pengolahan pati sagu di kilang sagu kering sama halnya dengan di kilang sagu basah, namun ada penambahan proses yaitu pencucian dan pengeringan pati. Nilai rendemen pengolahan sagu kering sebanyak $18 \%$, sehingga dari satu tual sagu dengan berat $100 \mathrm{~kg}$ yang diolah menghasilkan 18 kg sagu kering. Proses mekanik untuk mengekstrak pati sagu pada kilang tradisional masih belum efisien, karena masih banyaknya pati yang masih terkandung didalam empulur yang tidak dapat dipisahkan (Karim et al., 2008). Perlu adanya penambahan proses enzimatik untuk meningkatkan rendemen dan kualitas pati (Karim et al., 2008).

Kilang sagu kering memiliki teknologi yang beragam dalam proses pengeringan pati sagu dan kebanyakan menggunakan cara yang konvensional dengan dijemur sinar matahari. Beberapa kilang sudah menggunakan flash dryer dalam proses pengeringannya, yaitu mesin pengeringan dengan sistem kerja otomatis sehingga dapat menghasilkan sagu kering lebih cepat tanpa tergantung dengan cuaca.

Permasalahan dari sisi kualitas menjadi penting bagi kilang sagu kering karena aplikasi sebagai bahan baku pada industri selanjutnya sangat kuat dipengaruhi oleh kualitas pati. Beberapa masalah kualitas yang terkait dengan pati sagu adalah viskositas yang tidak konsisten, kadar air tidak seragam, bau yang menyimpang, kadar serat tinggi dan warna pati kusam (Karim et al., 2008).
Pati yang diproduksi oleh kilang sagu skala kecil biasanya memiliki kualitas yang bervariasi, tidak seluruhnya putih, masih mengandung sisa serat dan butiran pati sering terfermentasi melalui aktivitas mikroba sehingga menjadi keterbatasan di pasar internasional (Singhal et al., 2007).

\section{PT NSP}

Pada tahun 2010, PT NSP mengakuisisi lahan konsesi seluas 21.620 ha di Kepulauan Meranti dan 6.000 ha yang sudah ditanami pohon sagu secara monokultur. Budidaya sagu di Kepulauan Meranti tidak hanya dilakukan oleh petani kecil namun juga dilakukan pihak swasta yakni PT NSP dengan kontribusi sebanyak 21\% dari total area sagu (Metaragakusuma et al., 2017). PT NSP juga memiliki kilang sagu kering yang sudah mulai beroperasi pada tahun 2011 dengan kapasitas produksi 100 ton sagu kering per harinya (Sampoerna Agro, 2017). Produk sagu kering yang dihasilkan PT NSP ini dengan merek dagang "Prima Starch" dan sudah didistribusikan ke pasar domestik maupun internasional. Produk sagu yang dihasilkan PT NSP dikategorikan ke dalam 3 kelas yaitu Prima starch Blue yang dikhususkan untuk kelas industri non pangan, Prima starch green untuk kelas industri pangan dan Prima starch jumbo bag untuk kelas ekspor.

\section{Pabrik Sohun}

Pati sagu utamanya digunakan pada industri pangan seperti pembuatan bihun dan sohun (Ehara et al., 2018). Sagu menghasilkan pati yang bening ketika direbus sehinga ciri tersebut sangat ideal untuk pembuatan sohun (Ehara et al., 2018). Proses produksi sohun dimulai dari pencucian pati sagu basah di tangki berpengaduk, pemasakan, pengekstrusian, penjemuran dengan sinar matahari dan pengemasan. Rendemen pembuatan sohun sekitar $40 \%$. Produk sohun dijual ke pengumpul lokal dengan harga Rp 15.000 per kg.

Selain sohun, produk yang dihasilkan oleh pabrik sohun yaitu tepung hunkwe. Tepung ini biasanya digunakan pada pembuatan aneka kue tradisional, cendol dan bubur. Pada umumnya tepung hunkwe ini dibuat dari pati kacang hijau, namun dengan pati sagu produk tepung hunkwe juga memiliki rasa dan aroma yang khas. Proses pengolahan dimulai dari pencucian pati sagu basah sama halnya dengan sohun kemudian pengeringan dengan sinar matahari, penambahan bubuk vanili untuk mengurangi bau dan terakhir pengemasan.

\section{Industri Rumah Tangga (IRT)}

Mie sagu diolah secara manual oleh industri rumah tangga menggunakan peralatan tradisional oleh masyarakat lokal (Metaragakusuma et al. 2016). Bahan baku sagu basah diperoleh industri rumah tangga dari kilang sagu. Proses pengolahan mie sagu dimulai dari bahan baku sagu basah dicuci 
untuk menghilangkan ampas sagu yang masih menempel pada pati, selanjutnya sagu basah dibentuk seperti bola untuk kemudian direbus. Bola sagu yang telah direbus, dipipihkan dengan mesin double roll manual (sheeting) dan dilakukan perebusan yang kedua. Sagu lembaran dikering anginkan dalam ruangan selama satu malam. Proses selanjutnya adalah pemotongan sagu lembaran menjadi untaian sagu menggunakan mesin cutting (mesin pemotong mie terigu) dan pengemasan. Rendemen pembuatan mie sagu ini sebanyak $80 \%$ dari sagu basah yang diolah.

Pemasaran mie sagu pada umumnya dijual ke pengumpul lokal, yang selanjutnya dari pengumpul lokal tersebut mendistribusikan kembali ke warung-warung makan yang menyediakan menu mie sagu. Mie sagu merupakan makanan khas Kepulauan Meranti yang disajikan dalam bentuk olahan rebus maupun goreng. Mie sagu yang dihasilkan industri rumah tangga ini masih dalam bentuk semi basah, sehingga tidak bisa disimpan dalam waktu yang lama dengan maksimum penyimpanan tiga minggu. Hal ini berdampak pada cakupan pemasaran hanya wilayah sekitar Kepulauan Meranti.

\section{Koperasi Harmonis}

Koperasi Harmonis merupakan organisasi dari 43 kilang sagu kering yang fungsi utamanya memfasilitasi pengiriman pati sagu kering dari hasil produksi kilang sagu binaannya untuk kemudian didistribusikan ke Cirebon (Jawa Barat) lewat jalur laut. Sagu kering didistribusikan kepada Perusahaan Dagang (PD) yang ada di Cirebon. Dalam satu bulan Koperasi Harmonis bisa melakukan 3-4 kali pengiriman dengan rata-rata satu kali pengiriman sebanyak 1.000 ton. Tidak semua hasil produksi dari kilang sagu anggota dari Koperasi Harmonis mampu didistribusikan setiap pengirimannya, karena terbatasnya kapasitas kapal pengangkut, sehingga menyebabkan tumpukan sagu kering di kilangkilang sagu.

\section{PT Saweri Gading}

PT Saweri Gading atau masyarakat Desa Sungai Tohor lebih mengenalnya dengan sebutan Toke Asiong, merupakan aktor pengumpul sekaligus distributor sagu basah. Setiap bulan rata-rata 1.000 ton sagu basah didistribusikan ke kilang sagu yang berada di Batu pahat, Malaysia melalui jalur laut. Posisi Kepulauan Meranti yang berdekatan dengan Malaysia menjadikan pengiriman sagu basah relatif singkat yaitu sekitar 4 jam. Sagu basah dikumpulkan oleh PT Saweri Gading melalui 14 kilang sagu basah yang berada di Desa Sungai Tohor dengan harga sagu basah yang dibeli Rp 1.800 per kg.

PT Saweri Gading sudah memiliki keterikatan yang cukup lama dengan pemilik kilang sagu basah di Desa Sungai Tohor. Hubungan tersebut sudah terjadi sejak tahun 90 an. Pemilik kilang sagu juga bisa memperoleh pinjaman dari PT. Saweri Gading untuk keperluan biaya produksi. Hal ini menyebabkan pemilik kilang terikat dalam menjual hasil produksinya dan harga lebih ditentukan oleh PT. Saweri Gading.

\section{Distributor Individu}

Distributor merupakan individu yang fungsi utamanya memfasilitasi pengiriman sagu kering dari kilang sagu yang tidak tergabung dengan Koperasi Harmonis. Ada sekitar 29 kilang sagu kering yang tidak tergabung dengan Koperasi Harmonis, sehingga pengiriman sagu kering melalui aktor distributor individu tersebut. Sama halnya dengan Koperasi Harmonis, distributor sagu kering juga mendistribusikan sagu ke Cirebon, Jawa Barat melalui jalur laut.

\section{Analisis Margin Pemasaran}

Pada negara berkembang, lemahnya infrastruktur, transportasi dan komunikasi meningkatkan besarnya margin pemasaran yang disebabkan tingginya biaya pengiriman hasil produksi komoditas lokal ke lokasi pasar untuk dikonsumsi (Mumbeya, 2011). Pada Tabel 1, perhitungan margin pemasaran dilakukan pada setiap rantai nilai agroindustri sagu yang terdiri dari rantai nilai sagu kering ekspor, sagu kering lokal, sagu basah, sohun, tepung hunkwe dan mie sagu. Setiap rantai nilai tersebut terdapat aktor yang terlibat di dalamnya dengan fungsi yang berbeda-beda antara lain :

1. Rantai nilai sagu kering ekspor : Petani > Pedagang tual $>$ Kilang sagu PT. NSP > Importir Jepang

2. Rantai nilai sagu kering lokal : Petani > Pedagang tual > Kilang sagu kering (rakyat) > Koperasi Harmonis > PD. Cirebon

3. Rantai nilai sagu basah : Petani $>$ Pedagang tual $>$ Kilang sagu basah > PT. Saweri Gading (SG) > Kilang sagu Malaysia

4. Rantai nilai sohun : Petani > Pedagang tual > Kilang sagu basah $>$ Pabrik sohun $>$ Pengumpul lokal

5. Rantai nilai tepung hunkwe : Petani > Pedagang tual > Kilang sagu basah > Pabrik sohun > Pengumpul lokal

6. Rantai nilai mie sagu : Petani $>$ Pedagang tual $>$ Kilang sagu basah > Industri rumah tangga > Pengumpul lokal

Berdasarkan Tabel 1, asumsi semua aktor petani menjual hasil produksinya kepada pedagang tual tidak langsung ke kilang sagu. Dari pedagang tual disalurkan kembali ke kilang sagu kering dan basah. Seperti pada rantai nilai sagu kering ekspor, pedagang tual menyalurkan tualnya kepada kilang sagu milik PT. NSP, sedangkan rantai nilai lainnya aktor pedagang tual menyalurkan ke kilang sagu rakyat (kering dan basah). 
Tabel 1. Margin pemasaran rantai nilai agroindustri sagu

\begin{tabular}{|c|c|c|c|c|c|c|}
\hline & \multicolumn{6}{|c|}{ Rantai nilai (Rp/kg) } \\
\hline & $\begin{array}{l}\text { Sagu kering } \\
\text { ekspor }\end{array}$ & $\begin{array}{c}\text { Sagu kering } \\
\text { lokal }\end{array}$ & Sagu basah & Sohun & $\begin{array}{l}\text { Tepung } \\
\text { hunkwe }\end{array}$ & Mie sagu \\
\hline \multicolumn{7}{|l|}{ Petani } \\
\hline $\mathrm{HJ}$ & 250 & 250 & 250 & 250 & 250 & 250 \\
\hline MP & - & - & - & - & - & - \\
\hline \multicolumn{7}{|l|}{ Pedagang tual } \\
\hline $\mathrm{HP}$ & 250 & 250 & 250 & 250 & 250 & 250 \\
\hline $\mathrm{HJ}$ & 400 & 400 & 400 & 400 & 400 & 400 \\
\hline MP & 150 & 150 & 150 & 150 & 150 & 150 \\
\hline \multicolumn{7}{|l|}{ Kilang sagu } \\
\hline $\mathrm{HP}$ & 400 & 400 & 400 & 400 & 400 & 400 \\
\hline $\mathrm{HJ}$ & 7.552 & 5.000 & 1.800 & 2.000 & 2.000 & 2.500 \\
\hline MP & 7.152 & 4.600 & 1.400 & 1.600 & 1.600 & 2.100 \\
\hline \multicolumn{7}{|c|}{ Pabrik Sohun / IRT } \\
\hline HP & & & & 2.000 & 2.000 & 2.500 \\
\hline $\mathrm{HJ}$ & & & & 15.000 & 7.000 & 7.000 \\
\hline MP & & & & 13.000 & 5.000 & 4.500 \\
\hline \multicolumn{7}{|c|}{ K.Harmonis/ PT. SG } \\
\hline HP & & 5.000 & 1.800 & & & \\
\hline $\mathrm{HJ}$ & & 5.050 & 3.800 & & & \\
\hline MP & & 50 & 2.000 & & & \\
\hline Tujuan Pasar & Importir Jepang & PD. Cirebon & KS. Malaysia & P. Lokal & P. Lokal & P. Lokal \\
\hline
\end{tabular}

Satu tual dibeli dengan harga Rp 400 per $\mathrm{kg}$. Setelah diolah menjadi pati sagu, untuk pasar ekspor ke Jepang dijual dengan harga Rp 7.552 per $\mathrm{kg}$ sedangkan pasar ke Cirebon dengan harga $\mathrm{Rp}$ 5.000 per kg dalam bentuk sagu kering.

Pada rantai nilai sagu basah, aktor PT. Saweri Gading memperoleh margin pemasaran lebih tinggi dari kilang sagu, dengan perolehan margin sebesar Rp 2.000 per kg. PT. Saweri Gading membeli sagu basah senilai Rp 1.800 per kg dari aktor kilang sagu basah dan dijual kembali ke kilang sagu Malaysia seharga Rp 3.800. Pada rantai nilai ini aktor kilang sagu basah hanya memperoleh margin Rp 1.400 per kg. Pada rantai nilai sagu kering, aktor kilang sagu memperoleh margin Rp 4.600 per $\mathrm{kg}$. Pabrik sohun memperoleh margin pemasaran terbesar dari semua aktor yang terlibat. Perolehan margin pemasaran tersebut sebesar Rp 13.000 per kg pada rantai nilai sohun, sedangkan pada rantai nilai tepung hunkwe pabrik sohun hanya memperoleh margin pemasaran sebesar Rp 5.000 per kg.

\section{Analisis Nilai Tambah}

Faktor-faktor yang mempengaruhi nilai tambah untuk pengolahan dapat dikategorikan menjadi dua yaitu faktor teknis dan faktor pasar. Faktor teknis yang berpengaruh adalah kapasitas produksi, jumlah bahan baku yang digunakan dan tenaga kerja, sedangkan faktor pasar yang berpengaruh adalah harga output, upah tenaga kerja, harga bahan baku dan nilai input lain (Rachman, 2016). Pada Tabel 2, analisis nilai tambah dilakukan pada setiap produk yang dihasilkan oleh aktor rantai nilai agroindustri sagu. Produk tersebut mulai dari tual yang dihasilkan aktor pedagang tual, sagu basah dan sagu kering yang dihasilkan kilang sagu (rakyat), sohun dan tepung hunkwe yang dihasilkan pabrik sohun dan terakhir mie sagu yang dihasilkan oleh industri rumah tangga. Penelitian ini tidak dapat mengukur nilai tambah produk sagu kering yang dihasilkan oleh PT. NSP karena terbatasnya akses dalam pengumpulan data.

Pada Tabel 2, aktor kilang sagu kering memiliki kapasitas produksi harian yang lebih besar dibandingkan kilang sagu basah. Dalam satu hari, kilang sagu kering mampu menghasilkan $7.200 \mathrm{~kg}$ atau 7,2 ton sagu kering (baris no.1), sedangkan kilang sagu basah menghasilkan $3.150 \mathrm{~kg}$ atau 3,15 ton. Rata-rata jumlah pekerja di kilang sagu kering sebanyak 28 orang dengan total 10 jam kerja setiap harinya, sehingga bila dikalikan input tenaga kerja menjadi 280 jam (Baris no. 3), sedangkan pekerja di kilang sagu basah rata-rata sebanyak 3 orang dengan total jam kerja 12 jam mulai dari pukul 6 pagi sampai 6 sore sehingga input tenaga kerja menjadi 36 jam per hari.

Nilai output dari sagu kering senilai Rp 900 per kg. Nilai tersebut diperoleh dari hasil perkalian antara harga output (sagu kering) $\mathrm{Rp} 5.000$ per $\mathrm{kg}$ dengan rendemen sagu kering $18 \%$. Dari perolehan nilai output tersebut dikurangi dengan input bahan baku Rp 400 per kg, input kemasan Rp 100 per kg dan input energi Rp 179 per kg, sehingga nilai tambah yang diperoleh produk sagu kering sebesar $\mathrm{Rp} 221$ per $\mathrm{kg}$. Perolehan nilai tambah tersebut sangat rendah bila dibandingkan dengan nilai tambah produk sohun Rp 3.450 per kg. 
Tabel 2. Nilai tambah produk agroindustri sagu

\begin{tabular}{|c|c|c|c|c|c|c|c|}
\hline \multicolumn{2}{|r|}{ Output, Input dan Harga } & Tual & $\begin{array}{c}\text { Sagu } \\
\text { basah }\end{array}$ & $\begin{array}{c}\begin{array}{c}\text { Sagu } \\
\text { kering }\end{array} \\
\end{array}$ & Sohun & $\begin{array}{l}\text { Tepung } \\
\text { hunkwe }\end{array}$ & $\begin{array}{l}\text { Mie } \\
\text { sagu }\end{array}$ \\
\hline 1 & Output (kg/hari) & 3.000 & 3.150 & 7.200 & 300 & 200 & 100 \\
\hline 2 & Input bahan baku (kg/hari) & 3.000 & 9.000 & 40.000 & 750 & 400 & 125 \\
\hline 3 & Input tenaga kerja (jam/hari) & 24 & 36 & 280 & 140,8 & 52,8 & 32 \\
\hline 4 & Rendemen (\%) & 1 & 0,35 & 0,18 & 0,4 & 0,5 & 0,8 \\
\hline 5 & Koefisien tenaga kerja (jam/kg) & 0,01 & 0,00 & 0,01 & 0,19 & 0,13 & 0,26 \\
\hline 6 & Harga output $(\mathrm{Rp} / \mathrm{kg})$ & 400 & 1.800 & 5.000 & 15.000 & 7.000 & 7.000 \\
\hline 7 & Upah tenaga kerja (Rp/jam) & 12.500 & 8.750 & 7.500 & 3.125 & 3.125 & 6.250 \\
\hline \multicolumn{8}{|c|}{ Pendapatan dan keuntungan } \\
\hline 8 & Input bahan baku $(\mathrm{Rp} / \mathrm{kg})$ & 250 & 400 & 400 & 2.000 & 2.000 & 2.500 \\
\hline \multirow[t]{4}{*}{9} & Input lainnya (Rp/kg) & & & & & & \\
\hline & Bahan baku tambahan & 0 & 0 & 0 & 0 & 500 & 0 \\
\hline & Kemasan & 0 & 0 & 100 & 500 & 500 & 500 \\
\hline & Energi & 19,65 & 49 & 179 & 50 & 30 & 50 \\
\hline 10 & Nilai output (Rp/kg) & 400 & 630 & 900 & 6.000 & 3.500 & 5.600 \\
\hline 11 & Nilai tambah $(\mathrm{Rp} / \mathrm{kg})$ & 130,35 & 181 & 221 & 3.450 & 470 & 2.550 \\
\hline 12 & Rasio nilai tambah (\%) & 0,33 & 0,29 & 0,25 & 0,58 & 0,13 & 0,46 \\
\hline 13 & Pendapatan tenaga kerja $(\mathrm{Rp} / \mathrm{kg})$ & 100 & 35 & 52,5 & 586,67 & 412,5 & 1600 \\
\hline 14 & Rasio tenaga kerja $(\%)$ & 0,77 & 0,19 & 0,24 & 0,17 & 0,88 & 0,63 \\
\hline 15 & Keuntungan (Rp/kg) & 30,35 & 146 & 168,5 & 2863,33 & 57,5 & 950 \\
\hline 16 & Rasio keuntungan (\%) & 0,08 & 0,23 & 0,19 & 0,48 & 0,02 & 0,17 \\
\hline
\end{tabular}

\section{Implikasi Manejerial}

Penemuan penelitian ini menawarkan prospek untuk meningkatkan produksi pada produk sohun. Produk tersebut memperoleh nilai tambah terbesar dibandingkan produk agroindustri sagu lainnya. Saat ini jumlah produksi sohun masih kecil dibandingkan dengan jumlah produksi dari sagu kering dan sagu basah. Tersedianya kapasitas bahan baku yang besar dari kilang sagu, aktor pabrik sohun perlu meningkatkan kapasitas produksi dan skala usahanya. Dilihat dari proses pengolahan dan teknologi yang digunakan, pengolahan sohun bisa dilakukan pada industri skala kecil, menengah dan juga besar.

Tersedianya akses pasar ekspor sagu kering ke Jepang yang telah dilakukan PT. NSP, aktor kilang sagu kering rakyat dan Koperasi Harmonis memiliki peluang untuk melakukan pengembangan pasar ke negara tersebut, dengan syarat dapat memenuhi standar mutu yang berlaku. Harga sagu kering ke Jepang Rp 7.552 per kg lebih tinggi dari harga ke Cirebon Rp 5.000 per kg, perbedaan harga yang cukup signifikan dengan kenaikan sekitar $50 \%$.

Aktor kilang sagu basah memiliki peluang untuk meningkatkan nilai tambah produknya dengan menambah proses pencucian dan pengeringan pati sehingga sebagian dari produksi dapat diolah menjadi sagu kering. Tersedianya akses pasar ke Cirebon dan pasar ekspor, hal ini dapat meningkatkan pendapatan aktor kilang sagu basah.

\section{KESIMPULAN DAN SARAN}

\section{Kesimpulan}

Penelitian ini telah memetakan rantai nilai agroindustri sagu di Kepulauan Meranti dengan aktivitas utama pada rantai nilai dimulai dari pembibitan, budidaya, pemanenan, pengolahan hulu, pengolahan hilir dan distribusi. Adapun aktor yang terlibat didalam tiap-tiap aktivitas tersebut meliputi pemasok bibit, petani sagu, PT. NSP, pedagang tual, kilang sagu basah, kilang sagu kering, pabrik sohun, industri rumah tangga, Koperasi Harmonis, distributor individu dan PT. Saweri Gading. Penelitian ini juga telah mengidentifikasi distribusi nilai pada sejumlah aktor yang terlibat. Pada rantai nilai sagu basah, aktor PT. Saweri Gading yang fungsinya sebagai distributor memperoleh margin pemasaran lebih tinggi dari kilang sagu basah dengan perolehan margin sebesar Rp 2.000 per kg, sedangkan aktor kilang sagu basah hanya memperoleh margin Rp 1.400 per kg. Produk sohun memperoleh nilai tambah terbesar dibandingkan produk agroindustri sagu lainnya yaitu sebesar Rp 3.450 per $\mathrm{kg}$, sedangkan sagu kering yang merupakan produk utama yang diperdagangkan dari Kepulauan Meranti hanya memperoleh nilai tambah Rp 221 per kg.

\section{Saran}

Perlu penelitian lebih lanjut pada rantai nilai sagu kering lokal dengan pasar ke Cirebon. Penelitian tersebut dapat mencakup lanjutan rantai mulai dari perusahan dagang yang menampung sagu kering dari Kepulauan Meranti sampai pada pabrik sohun yang mengolah sagu kering tersebut di Cirebon. Selain itu, perlu penelitian lebih lanjut pada rantai nilai sagu basah yang diekspor ke kilang sagu di Malaysia. Hal itu untuk mengetahui jenis produk yang dihasilkan dari kilang sagu tersebut dan tujuan pasar dari produk yang dihasilkan.

\section{UCAPAN TERIMA KASIH}

Penelitian dilaksanakan atas dukungan biaya dari Non Timber Forest Products - Exchange 
Programme (NTFP-EP) Indonesia pada tahun 2017 dengan nomor kontrak No.04/NTFP-EPIndonesia SSNC/V-2017.

\section{DAFTAR PUSTAKA}

Boateng. 2012. Evaluating the efficacy of focus group discussion (FGD) in qualitative social research. International Journal Business and Social Science. 1 (7).

Bujang K. 2010. Production and processing of sago: a food and fuel alternative. International Seminar On Sago \& Spices For Food Security.

Chagomoka T, Afari-Sefa V, Pitoro R. 2014. Value chain analysis of traditional vegetables from Malawi and Mozambique, International Food and Agribusiness Management Review. 17 (4):59-86.

Da Silva CA, Baker D, Shepherd AD, Jenane C, Miranda-Da-Cruz S. 2009. Agro-Industries for Development. CABI, UK.

Ehara H, Toyoda Y, Johnson DV. 2018. Sago Palm. Singapore (SG) : Springer open.

Elmendorf W dan Luloff A. 2006. Using key informant interviews to better understand open space conservation in a developing watershed. Arboriculture and urban forestry. 32 (2): 54-61.

FAO. 2006. Guidelines For Value Chain Analysis. Food and Agriculture Organization.

FAO. 2013. Expert Consultation on the Establishment of A Sago Network for Asia and the Pacific. Roundtable Report.

Hamidi W dan Elida S. 2018. Analysis of value added and development strategy of public sago agroindustry business in Kepulauan Meranti Regency. International Journal Scientific \& Technology Research. 7 (2).

Hayami Y, Kawagoe T, Morooka Y, Siregar M. 1987. Agricultural Marketing And Processing In Upland Java. A Perspective From A Sunda Village. CGPRT Centre. Bogor

Heinze S dan Andreas. 2007. Valuelinks Manual: The Methodology Of Value Chain Promotion. Eschborn, Germany: GTZ.

Jackson D, Mcdonald G, Dip G, Luck L, Waine M, Wilkes L. 2016. Some strategies to address the challenges of collecting observational data in a busy clinical environement. Collegian. 23: 47-52.

Kamal MM, Baini R, Mohamaddan S, Selaman OS, Zauzi NA, Rahman MR, Rahman NA, Chong KH, Atan MF, Samat NAS, Taib SNL, Othman AK. 2016. Effect of temperature to the properties of sago starch. IOP Conf. Series: Materials Science and Engineering. 206
Kaplinsky R dan Morris M. 2001. A Handbook for Value Chain Research, paper prepared for the IDRC, http://www.ids.ac.uk/ ids/global/pdfs/VchNov01.pdf

Karim AA, Pei-lang Tie A, Manan DMA, Zaidul ISM. 2008. Strach from the sago (metroxylon sagu) palm tree-properties, prospects, and challenges as a new industrial source for food and other uses. Comprehensive Reviews In Food Science and Food Safety. 7:215-228.

Kouwenhoven G, Nalla VR, dan Losoncz TL. 2012. Creating sustainable businesses by reducing food waste: a value chain framework for eliminating inefficiencies. International Food and Agribusiness Management Review. 15 (3).

Lie H, Rich KM, Kurwijila LR, Jervell AM. 2012. Improving smallholder livelihoods through local value chain development: a case study of goat milk yogurt in Tanzania. International Food and Agribusiness Management Review. 15 (3):55-86.

M4P. 2008. Making Value Chains Work Better for the Poor: A Toolbook for Practitioners of. Value Chain Analysis, Version 3. Making Markets Work Better for the Poor (M4P) Project, UK. Department for International Development (DFID). Agricultural Development International

Metaragakusuma AP, Katsuya O, Bai H. 2016. An Overview of The Traditional Use of Sago for Sago-based Food Industry in Indonesia. ICoA Conference Proceedings. 3.

Metaragakusuma AP, Osozawa K, dan Bai H. 2017. The current status of sago production in South Sulawesi: its market and challange as a new food-industry source. J-SustaiN. 5 (1) :32-46.

Mumbeya PN. 2011. A value chain and market integration analysis of the cassava market in the Democratic Republic of Congo, [Tesis]. Pretoria: University of Pretoria.

Naim HM, Yaakub AN, Hamdan DAA. 2016. Commercialization of sago through estate plantation scheme in Sarawak: The Way Forward. Hindawi Publishing Corporation International Journal Agronomy. http://dx.doi.org/10.1155/2016/8319542.

Nusantara AW, Baheri, dan Tondi L. 2014. Competitiveness analysis and development of agroindustry in southeast sulawesi. International Journal Business and Management Invention. 3 (3):80-86.

Phiri LY, Dzanja J, Kakota T, Hara M. 2013. Value chain analysis of lake malawi fish: a case study of oreochromis spp (chambo). International Journal Business and Social Science. 4 (2):170-181.

Rachman NM. 2016. Efisiensi jaringan distribusi rantai pasok daging sapi di Kota Bogor [Tesis]. Bogor: Institut Pertanian Bogor. 
Sampoerna Agro. 2017. Managing Challenge for Business Sustainability, Annual report 2016, Jakarta, Indonesia

Singhal RS, Kennedy JF, Gopalakrishnan SM, Kaczmarek A, Knill CJ, Akmar PF. 2008. Industrial production, processing, and utilization of sago palm-derived products. Carbohydrate Polymers. 72:1-20.

Sunarti TC, Yanti SD, dan Ruriani E. 2017. Twosteps microwave-assisted treatment on acid hydrolysis of sago pith for bioethanol production. IOP Conf. Series: Earth and Environmental Science. $65 . \quad$ doi :10.1088/1755-1315/65/1/012052.

Trienekens JH. 2011. Agricultural value chains in developing countries a framework for analysis. International Food and Agribusiness Management Review. 14 (2). 51-83.

Watabaji MD, Molnar A, Dora MK, Gellynck X. 2016. The influence of value chain integration on performance: an empirical study of the malt barley value chain in Ethiopia. International Food and Agribusiness Management Review. 19 (4) : 79 - 94. doi.org/10.22434/IFAMR2015.0201 